\title{
Maternal diabetes and risk of childhood acute lymphoblastic leukaemia in the offspring
}

\author{
Signe Holst Søegaard ${ }^{*}, 1$ Klaus Rostgaard ${ }^{1}$, Mads Kamper-Jørgensen ${ }^{2}$, Kjeld Schmiegelow ${ }^{3,4}$ \\ and Henrik Hjalgrim ${ }^{1,5}$ \\ ${ }^{1}$ Department of Epidemiology Research, Statens Serum Institut, Copenhagen DK-2300, Denmark; ${ }^{2}$ Department of Public Health, \\ University of Copenhagen, Copenhagen DK-1123, Denmark; ${ }^{3}$ Department of Paediatrics and Adolescent Medicine, University \\ Hospital Rigshospitalet, Copenhagen DK-2100, Denmark; ${ }^{4}$ Institute of Clinical Medicine, University of Copenhagen, Copenhagen \\ DK-2200, Denmark and ${ }^{5}$ Department of Haematology, University Hospital Rigshospitalet, Copenhagen DK-2100, Denmark
}

Background: Maternal diabetes may be linked to childhood acute lymphoblastic leukaemia (ALL) in the offspring.

Methods: We assessed the association between maternal pregestational or gestational diabetes and offspring risk of childhood ALL in a register-based study, including all singletons born in Denmark during 1996-2015 ( $n=1187$ 482).

Results: Adjusted hazard ratios of childhood ALL were 2.91 (95\% confidence interval (CI): 1.30-6.51) for maternal pregestational diabetes and 1.75 (95\% Cl: 1.02-2.98) for maternal gestational diabetes. Paternal diabetes did not alter offspring ALL risk, and we found no association between offspring ALL and later maternal risk of diabetes.

Conclusions: Regardless that absolute ALL risk among offspring of women with diabetes remains low, our findings suggest that characteristics of the diabetic intrauterine environment promote ALL development. This offers a setting for future research into the biological mechanisms underlying childhood ALL.

Acute lymphoblastic leukaemia (ALL) is the commonest childhood cancer, with an annual incidence of approximately 4 in 100000 person-years among children below 15 years of age in developed countries (Hjalgrim et al, 2003a; Stiller et al, 2006). Apart from certain genetic syndromes, accounting for less than $5 \%$ of cases (Stieglitz and Loh, 2013) and a well-established association with high birth weight (Hjalgrim et al, 2003b; Caughey and Michels, 2009), risk factors for childhood ALL remain largely unknown. The prenatal origin of most childhood ALL cases has been irrefutably demonstrated by the presence of clone-specific mutations in patient neonatal blood spots (Wiemels et al, 1999; Hjalgrim et al, 2002; Gruhn et al, 2008). While the intrauterine development of preleukaemic cell clones remains unexplained, the association between birth weight and childhood ALL risk suggests that it is related to foetal growth. In addition, a recent study reported an increased ALL risk in children born to women with diabetes (Contreras et al, 2016), whose offspring are at increased risk of macrosomia (Schmidt et al, 2001; Crowther et al, 2005; Temple et al, 2006). However, it is unclear whether this association varies by type of maternal diabetes and between ALL subtypes, which may have distinct aetiologies.

We therefore evaluated the risk of ALL among offspring of women with pregestational or gestational diabetes in a cohort study, including all singletons born in Denmark during 1996-2015 identified using nationwide registers with detailed information on maternal antidiabetic medication and ALL subtypes.

\section{MATERIALS AND METHODS}

Based on the unique personal identifiers of the children and their parents, we linked information on birth characteristics obtained from the Danish Medical Birth Register (Knudsen and Olsen, 1998) with information on maternal diabetes recorded in the Danish National Patient Register (NPR) (Lynge et al, 2011). The NPR contains records of all hospitalisations since 1977, including outpatient contacts since 1995 with diagnoses classified according to the International Classification of Diseases (ICD) 8th (1977-

*Correspondence: SH Søegaard; E-mail: siho@ssi.dk

Received 29 May 2017; revised 16 August 2017; accepted 7 September 2017; published online 3 October 2017

(C) 2018 Cancer Research UK. All rights reserved 0007-0920/18 
Table 1. Person-years of follow-up and number of cases of childhood acute lymphoblastic leukaemia (ALL), according to baseline characteristics and parental diabetes among singletons born in Denmark during 1996-2015

\begin{tabular}{|c|c|c|c|c|c|}
\hline & Person-years at risk (\%) & $\begin{array}{l}\text { ALL } \\
N(\%)\end{array}$ & $\begin{array}{l}\text { BCP } \\
N(\%)\end{array}$ & $\begin{array}{c}\text { ETV6-RUNX1/HeH } \\
N(\%)\end{array}$ & $\begin{array}{c}\text { Total cohort } \\
N(\%)\end{array}$ \\
\hline Total & $11196998(100)$ & $492(100)$ & $431(100)$ & $266(100)$ & $1187482(100)$ \\
\hline $\begin{array}{l}\text { Sex } \\
\text { Boys } \\
\text { Girls }\end{array}$ & $\begin{array}{l}5745498(51.3) \\
5451500(48.7)\end{array}$ & $\begin{array}{l}262(53.3) \\
230(46.7)\end{array}$ & $\begin{array}{l}222(51.5) \\
209(48.5)\end{array}$ & $\begin{array}{l}145(54.5) \\
121(45.5)\end{array}$ & $\begin{array}{l}609514(51.3) \\
577968(48.7)\end{array}$ \\
\hline $\begin{array}{l}\text { Ethnicity } \\
\text { Danish } \\
\text { Other }\end{array}$ & $\begin{array}{l}9334246(83.4) \\
1862752(16.6)\end{array}$ & $\begin{array}{r}423(86.0) \\
69(14.0)\end{array}$ & $\begin{array}{r}370(85.8) \\
61(14.2)\end{array}$ & $\begin{array}{r}233(87.6) \\
33(12.4)\end{array}$ & $\begin{array}{l}966532(81.4) \\
220950(18.6)\end{array}$ \\
\hline $\begin{array}{l}\text { Maternal smoking } \\
\text { No } \\
\text { Yes }\end{array}$ & $\begin{array}{l}9292764(83.0) \\
1904234(17.0)\end{array}$ & $\begin{array}{r}424(86.2) \\
68(13.8)\end{array}$ & $\begin{array}{r}374(86.8) \\
57(13.2)\end{array}$ & $\begin{array}{r}229(86.1) \\
37(13.9)\end{array}$ & $\begin{array}{r}1003943(84.5) \\
183539(15.5)\end{array}$ \\
\hline $\begin{array}{l}\text { Maternal diabetes } \\
\text { No } \\
\text { Pregestational } \\
\text { Gestational }\end{array}$ & $\begin{array}{c}10976192(98.0) \\
46598(0.4) \\
174208(1.6)\end{array}$ & $\begin{aligned} 472 & (95.9) \\
6 & (1.3) \\
14 & (2.8)\end{aligned}$ & $\begin{aligned} 415 & (96.3) \\
5 & (1.2) \\
11 & (2.5)\end{aligned}$ & $\begin{aligned} 253 & (95.1) \\
4 & (1.5) \\
9 & (3.4)\end{aligned}$ & $\begin{array}{r}1157767(97.5) \\
5409(0.5) \\
24306(2.0)\end{array}$ \\
\hline $\begin{array}{l}\text { First-time pregestational diabetes treatment } \\
\text { Insulin }\end{array}$ & $35000(75.1)$ & $5(83.3)$ & $5(100)$ & $4(100)$ & $3857(71.3)$ \\
\hline $\begin{array}{l}\text { Age at pregestational diabetes diagnosis } \\
\quad<30 \\
\quad \geqslant 30\end{array}$ & $\begin{array}{r}40081(86.0) \\
6517(14.0)\end{array}$ & $\begin{array}{l}6(100) \\
0(0)\end{array}$ & $\begin{array}{l}5(100) \\
0(0)\end{array}$ & $\begin{array}{l}4(100) \\
0(0)\end{array}$ & $\begin{array}{r}4554(84.2) \\
855(15.8)\end{array}$ \\
\hline $\begin{array}{l}\text { Paternal diabetes } \\
\text { No } \\
\text { Yes }\end{array}$ & $\begin{array}{c}10963593(98.7) \\
148517(1.3)\end{array}$ & $\begin{array}{c}482(98.6) \\
7(1.4)\end{array}$ & $\begin{array}{r}423 \text { (98.8) } \\
5(1.2)\end{array}$ & $\begin{aligned} 261 & (99.2) \\
2 & (0.8)\end{aligned}$ & $\begin{array}{r}1165777 \text { (98.2) } \\
21435(1.8)\end{array}$ \\
\hline
\end{tabular}

1993) and 10th revision (1994-). Children registered with Down syndrome in the NPR (ICD10 code Q90) were excluded from the cohort $(0.08 \%)$ due to their increased risk of childhood leukaemia with distinct biology and aetiology (Izraeli et al, 2014).

We defined maternal pregestational diabetes as NPR registrations of ICD 8 codes 249 or 250 , or ICD10 codes E10-E11 or E13-E14 before gestation. Gestational diabetes was defined as any of the listed ICD codes for diabetes registered for the first time during pregnancy including also ICD10 code O24. For women registered with pregestational diabetes, we retrieved additional information on first-time prescriptions for antidiabetic treatment from the Danish Register of Medicinal Product Statistics (established 1995) (Anatomic Therapeutic Chemical classification system codes A10A for insulin and $\mathrm{A} 10 \mathrm{~B}$ for oral antidiabetic medications).

ALL occurring before age 15 years was identified through linkage with the Nordic Society of Paediatric Haematology and Oncology leukaemia database (Schmiegelow et al, 2010).

The children were followed from birth until date of childhood ALL diagnosis, loss to follow-up/emigration, death, age 15 years, or 31 December 2015, whichever occurred first. We used Cox proportional hazards models with age as the underlying time scale to estimate hazard ratios (HRs) for childhood ALL.

Based on the potential of association with both maternal diabetes and childhood ALL, we adjusted for a number of covariates identified in the Danish Medical Birth Register and the Danish Civil Registration System (Pedersen, 2011). These included the potential confounders maternal age at delivery (continuous), ethnicity (Danish or other), birth order $(1,2$ or $\geqslant 3$ ), maternal smoking during pregnancy (yes or no) and birth cohort (5-year intervals), and the potential mediators birth weight (100-g intervals), gestational age (1-week intervals) and mode of delivery (caesarean section or vaginal) (Hjalgrim et al, 2004; Chang et al, 2006; Thomopoulos et al, 2015; Contreras et al, 2017). Further, we tested the heterogeneity of the association between maternal diabetes and offspring risk of ALL by birth weight using the median as cut-off ( $<3540 \mathrm{~g} v s \geqslant 3540 \mathrm{~g})$.

Childhood ALL was grouped as: (1) all types combined; (2) B-cell precursor ALL; (3) and a group comprising the frequent, prenatally initiated karyotypes (ETV6/RUNX1-positive and highhyperdiploidy ALL).

In subsequent analyses we tested whether paternal diabetes was associated with childhood ALL. Also, we assessed the risk of developing diabetes in women with and without offspring with ALL. In this analysis, we included women with $\geqslant 1$ live births between 1996 and 2015, followed from their first birth after 1995 until diabetes diagnosis (outcome), death, emigration, or 31 December 2015, excluding women with diabetes diagnosed before start of follow-up. History of offspring ALL was included as a timevarying variable (exposed from date of offspring ALL diagnosis) with adjustment for maternal age, parity and year of delivery.

All analyses were conducted using SAS statistical software (9.4, SAS Institute, Inc., Cary, NC, USA) with 95\% confidence intervals (CIs) based on Likelihood-ratio tests. 
Table 2. Association between maternal diabetes, paternal diabetes and risk of childhood acute lymphoblastic leukaemia (ALL) among singletons born in Denmark during 1996-2015

\begin{tabular}{|c|c|c|c|c|c|c|}
\hline & \multicolumn{2}{|c|}{ ALL } & \multicolumn{2}{|c|}{ BCP } & \multicolumn{2}{|c|}{ ETV6-RUNX1/HeH } \\
\hline & $\begin{array}{l}\text { Crude HR } \\
(95 \% \mathrm{Cl})\end{array}$ & $\begin{array}{c}\text { Adjusted HR } \\
(95 \% \mathrm{Cl})\end{array}$ & $\begin{array}{c}\text { Crude HR } \\
(95 \% \mathrm{Cl})\end{array}$ & $\begin{array}{l}\text { Adjusted HR } \\
(95 \% \mathrm{Cl})\end{array}$ & $\begin{array}{l}\text { Crude HR } \\
(95 \% \mathrm{Cl})\end{array}$ & $\begin{array}{c}\text { Adjusted HR } \\
(95 \% \mathrm{Cl})\end{array}$ \\
\hline \multicolumn{7}{|c|}{ Maternal diabetes ${ }^{a, b}$} \\
\hline $\begin{array}{l}\text { No (ref.) } \\
\text { Pregestational } \\
\text { Gestational }\end{array}$ & $\begin{array}{c}1.00 \\
2.92(1.30-6.53) \\
1.73(1.02-2.95)\end{array}$ & $\begin{array}{c}1.00 \\
2.91(1.30-6.51) \\
1.75(1.02-2.98)\end{array}$ & $\begin{array}{c}1.00 \\
2.76(1.14-6.66) \\
1.54(0.85-2.80)\end{array}$ & $\begin{array}{c}1.00 \\
2.75(1.14-6.65) \\
1.56(0.85-2.84)\end{array}$ & $\begin{array}{c}1.00 \\
3.61(1.35-9.68) \\
2.04(1.05-3.97)\end{array}$ & $\begin{array}{c}1.00 \\
3.58(1.33-9.62) \\
2.06(1.05-4.03)\end{array}$ \\
\hline \multicolumn{7}{|c|}{ Paternal diabetes $^{c}$} \\
\hline $\begin{array}{l}\text { No (ref.) } \\
\text { Yes }\end{array}$ & $\begin{array}{c}1.00 \\
1.23(0.58-2.59)\end{array}$ & $\begin{array}{c}1.00 \\
1.20(0.57-2.53)\end{array}$ & $\begin{array}{c}1.00 \\
1.01(0.42-2.45)\end{array}$ & $\begin{array}{c}1.00 \\
0.99(0.41-2.39)\end{array}$ & $\begin{array}{c}1.00 \\
0.68(0.17-2.71)\end{array}$ & $\begin{array}{c}1.00 \\
0.66(0.16-2.65)\end{array}$ \\
\hline \multicolumn{7}{|c|}{ 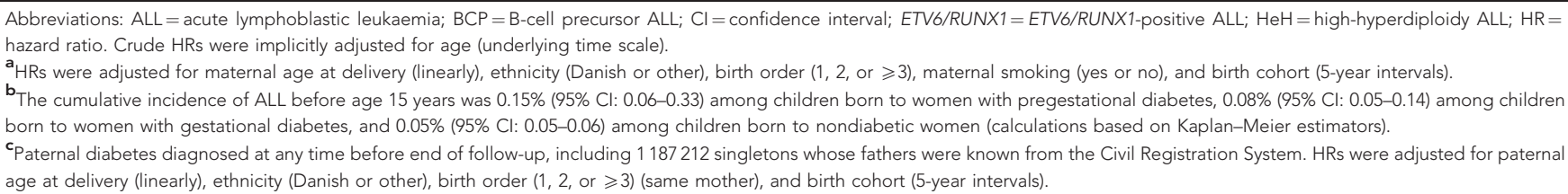 } \\
\hline
\end{tabular}

\section{RESULTS}

Among 1187482 studied singletons, 492 developed ALL before age 15 years (Table 1), corresponding to an annual incidence rate of 4.40 (95\% CI: 4.02-4.80) per 100000 person-years. In total, 5409 children were born to women with pregestational diabetes (mean birth weight: $3519 \mathrm{~g}$ ) of whom six developed ALL (mean birth weight: $3894 \mathrm{~g}$; mean age at diagnosis: 4.2 years, age range $2-8$ years). All mothers to these six children with ALL were diagnosed with diabetes before age 30 years and five mothers had received insulin as first-time antidiabetic treatment. Further, we identified 24306 children born to women with gestational diabetes (mean birth weight: $3537 \mathrm{~g}$ ) of whom 14 developed ALL (mean birth weight: $3707 \mathrm{~g}$; mean age at diagnosis: 3.4 years, age range 1-7 years).

After adjusting for potential confounders, childhood ALL risk among children born to women with pregestational or gestational diabetes was 2.91-fold (95\% CI: 1.30-6.51) and 1.75-fold (95\% CI: 1.02-2.98) increased, respectively, compared with children born to nondiabetic women (Table 2). In analysis of pregestational diabetes, HR were statistically significantly increased for B-cell precursor ALL and for the prenatally initiated karyotypes (ETV6-RUNX1 or highhyperdiploidy ALL), while HRs associated with gestational diabetes were only statistically significantly increased among the prenatally initiated karyotypes. The risk estimates remained unchanged in models including only potential confounders (Table 2) and both potential confounders and mediators, respectively (data not shown).

HRs for ALL associated with gestational diabetes did not differ in strata of birth weight (birth weight $<3540 \mathrm{~g}$ : $\mathrm{HR}=1.68,95 \% \mathrm{CI}$ : $0.75-3.81$ vs birth weight $\geqslant 3540$ g: $\mathrm{HR}=1.78,95 \% \mathrm{CI}: 0.88-3.61$; $p$ for interaction $=0.92$ ). Neither did we find statistically significant differences between the HRs for ALL associated with pregestational diabetes stratified by birth weight (birth weight <3540 g: $\mathrm{HR}=1.10, \quad 95 \% \quad \mathrm{CI}: 0.16-7.87$ vs birth weight $\geqslant 3540 \mathrm{~g}$ : $\mathrm{HR}=4.30,95 \% \mathrm{CI}: 1.77-10.43$; $p$ for interaction $=0.16$ ).

Paternal diabetes was not statistically significantly associated with childhood ALL risk (HR=1.20, 95\% CI: 0.57-2.53) (Table 2). Finally, we found no association between offspring ALL and later risk of diabetes in the mother ( $\mathrm{HR}=0.92,95 \% \mathrm{CI}$ : $0.46-1.85$, based on eight mothers diagnosed with diabetes after offspring ALL).

\section{DISCUSSION}

In this nationwide register-based cohort study, we found that the risk of childhood ALL in children born to women with pregestational or gestational diabetes was 2.9- and 1.7-fold increased, respectively.

The observed association with pregestational diabetes in our study is likely attributable to type 1 diabetes because the vast majority of these women had received insulin as first-time antidiabetic treatment and were diagnosed before age 30 years. However, the fact that gestational diabetes was also associated with offspring ALL risk suggests that the association with maternal diabetes is not exclusively related to the autoimmunity of type 1 diabetes.

Because of its level of detail regarding both maternal diabetes and offspring ALL, our investigation expands the existing literature on the association between the two conditions considerably. Recently, a statistically significantly 1.4 -fold increased ALL risk in offspring of women with pregestational diabetes and a statistically nonsignificantly 1.3-fold increased ALL risk in offspring of women with gestational diabetes were observed in a California birth record study (Contreras et al, 2016). However, unlike in our investigation, information was available on neither type of pregestational diabetes nor on ALL subtypes in the California study. Limitations of similar nature concerning exposure and outcome combined with small study populations have hampered the interpretation of other previous investigations reporting statistically non-significantly increased risks of ALL (McLaughlin et al, 2006; Milne et al, 2007) or of leukaemia (Petridou et al, 1997; Podvin et al, 2006) or statistically significantly increased risks of cancer overall (Westbom et al, 2002; Wu et al, 2012) in offspring of women with diabetes.

Not mirrored by similarly strong associations with paternal diabetes or later maternal diabetes, the increased ALL risk in children born to women with diabetes is unlikely to reflect shared genetic risk factors; rather it may reflect that circumstances characteristic of diabetic pregnancies such as intrauterine hyperglycaemia promote offspring ALL development. In support hereof, we observed that children born to women with pregestational diabetes who developed ALL weighed on average $400 \mathrm{~g}$ more than those who did not, suggesting that maternal hyperglycaemia was more pronounced in the former. Birth weight is positively associated with the level of insulin-like growth factor I, which could increase childhood ALL risk by causing proliferation of progenitor or preleukaemic cells (Ross et al, 1996). Moreover, maternal hyperglycaemia has been associated with a number of epigenetic modifications in the offspring (Ma et al, 2015), which potentially mediate the link between maternal diabetes and offspring's development of ALL.

Although we observed markedly increased relative risks, the cumulative incidence of childhood ALL in offspring of women with diabetes remains low, that is, 0.15 and $0.08 \%$ among children 
below 15 years of age born to women with pregestational and gestational diabetes, respectively.

The strengths of this study include its nationwide coverage, longitudinal and independent ascertainment of maternal diabetes and offspring ALL development as well as information on important covariates including birth weight. Contrary to previous investigations, our study included information on pregestational diabetes treatment and detailed information on ALL subtypes. Conversely, the low number of children with ALL born to women with pregestational or gestational diabetes had implications for the precision of risk estimates, reflected by the wide CIs. Finally, the apparent absence of association with paternal diabetes or later maternal diabetes was based on a small number of exposed events.

In conclusion, we found that maternal pregestational and gestational diabetes are risk factors for childhood ALL in the offspring. Further studies are needed to identify the biological mechanisms underlying this association.

\section{ACKNOWLEDGEMENTS}

This work was supported by the Danish Childhood Cancer Foundation (grant number 2014-50); the Arvid Nilsson Foundation and the Danish Cancer Research Foundation.

\section{CONFLICT OF INTEREST}

The authors declare no conflict of interest.

\section{REFERENCES}

Caughey RW, Michels KB (2009) Birth weight and childhood leukemia: A metaanalysis and review of the current evidence. Int J Cancer 124: 2658-2670.

Chang JS, Selvin S, Metayer C, Crouse V, Golembesky A, Buffler PA (2006) Parental smoking and the risk of childhood leukemia. Am J Epidemiol 163: 1091-1100.

Contreras ZA, Hansen J, Ritz B, Olsen J, Yu F, Heck JE (2017) Parental age and childhood cancer risk: a Danish population-based registry study. Cancer Epidemiol 49: 202-215.

Contreras ZA, Ritz B, Virk J, Cockburn M, Heck JE (2016) Maternal prepregnancy and gestational diabetes, obesity, gestational weight gain, and risk of cancer in young children: a population-based study in California. Cancer Causes Control 27: 1273-1285.

Crowther CA, Hiller JE, Moss JR, McPhee AJ, Jeffries WS, Robinson JS (2005) Effect of treatment of gestational diabetes mellitus on pregnancy outcomes. N Engl J Med 352: 2477-2486.

Gruhn B, Taub JW, Ge Y, Beck JF, Zell R, Häfer R, Hermann FH, Debatin K-M, Steinbach D (2008) Prenatal origin of childhood acute lymphoblastic leukemia, association with birth weight and hyperdiploidy. Leukemia 22: 1692-1697.

Hjalgrim LL, Madsen HO, Melbye M, Jørgensen P, Christiansen M, Andersen MT, Pallisgaard N, Hokland P, Clausen N, Ryder LP, Schmiegelow K, Hjalgrim H (2002) Presence of clone-specific markers at birth in children with acute lymphoblastic leukaemia. $\mathrm{Br} J$ Cancer 87: 994-999.

Hjalgrim LL, Rostgaard K, Schmiegelow K, Söderhäll S, Kolmannskog S, Vettenranta K, Kristinsson J, Clausen N, Melbye M, Hjalgrim H, Gustafsson G (2003a) Age- and sex-specific incidence of childhood leukemia by immunophenotype in the Nordic countries. J Natl Cancer Inst 95: 1539-1544.

Hjalgrim LL, Westergaard T, Rostgaard K, Schmiegelow K, Melbye M, Hjalgrim H, Engels EA (2003b) Birth weight as a risk factor for childhood leukemia: a meta-analysis of 18 epidemiologic studies. Am J Epidemiol 158: $724-735$.
Hjalgrim LL, Rostgaard K, Hjalgrim H, Westergaard T, Thomassen H, Forestier E, Gustafsson G, Kristinsson J, Melbye M, Schmiegelow K (2004) Birth weight and risk for childhood leukemia in Denmark, Sweden, Norway, and Iceland. J Natl Cancer Inst 96: 1549-1556.

Izraeli S, Vora A, Zwaan CM, Whitlock J (2014) How I treat ALL in Down's syndrome: pathobiology and management. Blood 123: 35-41.

Knudsen LB, Olsen J (1998) The Danish Medical Birth Registry. Dan Med Bull 45: 320-323.

Lynge E, Sandegaard JL, Rebolj M (2011) The Danish National Patient Register. Scand J Public Health 39: 30-33.

Ma RCW, Tutino GE, Lillycrop KA, Hanson MA, Tam WH (2015) Maternal diabetes, gestational diabetes and the role of epigenetics in their long term effects on offspring. Prog Biophys Mol Biol 118: 55-68.

McLaughlin CC, Baptiste MS, Schymura MJ, Nasca PC, Zdeb MS (2006) Birth weight, maternal weight and childhood leukaemia. Br J Cancer 94: $1738-1744$.

Milne E, Laurvick CL, Blair E, Bower C, De Klerk N (2007) Fetal growth and acute childhood leukemia: looking beyond birth weight. Am J Epidemiol 166: $151-159$.

Pedersen CB (2011) The Danish Civil Registration System. Scand J Public Health 39: 22-25.

Petridou E, Trichopoulos D, Kalapothaki V, Pourtsidis A, Kogevinas M, Kalmanti M, Koliouskas D, Kosmidis H, Panagiotou JP, Piperopoulou F, Tzortzatou F (1997) The risk profile of childhood leukaemia in Greece: a nationwide case-control study. Br J Cancer 76: 1241-1247.

Podvin D, Kuehn CM, Mueller BA, Williams M (2006) Maternal and birth characteristics in relation to childhood leukaemia. Paediatr Perinat Epidemiol 20: 312-322.

Ross Ja, Perentesis JP, Robison LL, Davies SM (1996) Big babies and infant leukemia: a role for insulin-like growth factor-1? Cancer Causes Control 7: 553-559.

Schmidt MI, Duncan BB, Reichelt AJ, Branchtein L, Matos MC, Costa e Forti A, Spichler ER, Pousada JM, Teixeira MM, Yamashita T (2001) Gestational diabetes mellitus diagnosed with a 2-h 75-g oral glucose tolerance test and adverse pregnancy outcomes. Diabetes Care 24: 1151-1155.

Schmiegelow K, Forestier E, Hellebostad M, Heyman M, Kristinsson J, So S (2010) Long-term results of NOPHO ALL-92 and ALL-2000 studies of childhood acute lymphoblastic leukemia. Leukemia 24: 345-354.

Stieglitz E, Loh ML (2013) Genetic predispositions to childhood leukemia. Ther Adv Hematol 4: 270-290.

Stiller CA, Marcos-Gragera R, Ardanaz E, Pannelli F, Almar Marques E, Canada Martinez A, Steliarova-Foucher E (2006) Geographical patterns of childhood cancer incidence in Europe, 1988-1997. Report from the Automated Childhood Cancer Information System project. Eur J Cancer 42: 1952-1960.

Temple RC, Aldridge VJ, Murphy HR (2006) Prepregnancy care and pregnancy outcomes in women with type 1 diabetes. Diabetes Care 29: 1744-1749.

Thomopoulos TP, Skalkidou A, Dessypris N, Chrousos G, Karalexi MA, Karavasilis TG, Baka M, Hatzipantelis E, Kourti M, Polychronopoulou S, Sidi V, Stiakaki E, Moschovi M, Loutradis D, Petridou ET (2015) Prelabor cesarean delivery and early-onset acute childhood leukemia risk. Eur J Cancer Prev 25: 155-161.

Westbom L, Aberg A, Källén B (2002) Childhood malignancy and maternal diabetes or other auto-immune disease during pregnancy. Br J Cancer $\mathbf{8 6}$ : 1078-1080.

Wiemels JL, Cazzaniga G, Daniotti M, Eden OB, Addison GM, Masera G, Saha V, Biondi A, Greaves MF (1999) Prenatal origin of acute lymphoblastic leukaemia in children. Lancet 354: 1499-1503.

Wu CS, Nohr EA, Bech BH, Vestergaard M, Olsen J (2012) Long-term health outcomes in children born to mothers with diabetes: a population-based cohort study. PLoS One 7: 1-7.

This work is published under the standard license to publish agreement. After 12 months the work will become freely available and the license terms will switch to a Creative Commons AttributionNonCommercial-Share Alike 4.0 Unported License. 